\title{
Influence of forage proportion and ensiling periods on physical characteristics and qualities of Panicum maximum (Ntchisi) and Stylosanthes guianensis silage
}

\section{Oluwafemi Adeyemi okukenu ( $\nabla$ femi_okukenu@yahoo.co.uk)}

Federal University of Agriculture Abeokuta College of Animal Science and Livestock Production https://orcid.org/0000-0002-6952-1336

\section{Sunday Olawale Okunogbe}

Federal University of Agriculture Abeokuta College of Animal Science and Livestock Production Rashidat Adewunmi Afolabi

Federal University of Agriculture Abeokuta College of Animal Science and Livestock Production Peter Aniwe Dele

Federal University of Agriculture Abeokuta College of Animal Science and Livestock Production

Bolanle Temitope Akinyemi

Federal University of Agriculture Abeokuta College of Animal Science and Livestock Production

\section{Ahmed Adeyemi Amisu}

Federal University of Agriculture Abeokuta College of Animal Science and Livestock Production

Alaba Olufunmilayo Jolaosho

Federal University of Agriculture Abeokuta College of Animal Science and Livestock Production

Olufemi Sunday Onifade

Federal University of Agriculture Abeokuta College of Animal Science and Livestock Production

\section{Research Article}

Keywords: Ensiling period, Forage conservation, Grass, Legume, Silage, Proportion

Posted Date: October 25th, 2021

DOl: https://doi.org/10.21203/rs.3.rs-985205/v1

License: (9) (1) This work is licensed under a Creative Commons Attribution 4.0 International License. Read Full License 


\section{Abstract}

This study was carried out to evaluate the effect of proportion of grass-legume mixtures and ensiling periods on the physical characteristics and qualities of Panicum maximum and Stylosanthes guainensis silage. The experiment was laid in a $2 \times 3$ factorial arrangement which comprised of two (2) forage proportions (100\% and 50\%:50\%) and three (3) ensiling periods (30, 60 and 90 days). Results showed that there was only significant $(\mathrm{p}<0.05)$ different on $\mathrm{pH}$ as affected by ensiling periods whereby the $\mathrm{pH}$ values decline as the ensiling periods increases. The highest $(p<0.05)$ CP $(10.75 \%)$ and NFC $(15.33 \%)$ contents was observed in equal proportion of $P$. maximum and $S$. guianensis silage. The effect of ensiling period effect on the proximate composition was significant $(\mathrm{p}<0.05)$ whereby $P$. maximum and $S$. guianensis ensiled for 90 days recorded the highest value for dry matter (DM) (96.88\%) and ether extract (EE) (5.50) while $P$. maximum and S. guianensis ensiled for 30 days had highest CP content of $12.70 \%$. Effect of proportion was significant $(\mathrm{p}<0.05)$ on the NDF, ADF and cellulose contents. Sole $P$. maximum silage had higher NDF (59.67\%), ADF (33.83\%) and cellulose $(29.17 \%)$ contents compared to other proportion. There was declined in NDF and ADF contents as the ensiling period extended from 30 to 90 days in which silage ensiled at 90 days had the least content of 54.00 and $32.25 \%$ respectively. It is therefore concluded that silage made from equal proportion of $P$. maximum and $S$. guainensis silage had the highest crude protein and low structural components.

\section{Introduction}

Nutrition is one of the significant management practiced in livestock production and it is the bed rock of animal performance; yet in case there are limited forages; and decrease in nutrient composition of the available forages during dry season, this poses a problem (Amole et al., 2011). However, available information shows that small ruminant industry would benefit if the animal received optimal nutrition. In Tropical Africa, majority of ruminant are raised on natural pastures which decrease in quality during the dry season (Bamikole, 1998). Lately, ruminants have likewise been raised on fodder tree and herbaceous legumes foliages since they supply nutrients, especially Nitrogen $(N)$, during the dry season when nutrients from grazing become qualitatively and quantitatively limited for grazing animals. These fodder trees and herbaceous legumes foliages serve as supplements depending on the ability to give essential nutrients to the rumen microbial populace and furthermore to satisfy animal requirements, both might increase the efficiency of feed usage (Elliot and McMeniman, 1987). In such manner, foliages from fodder legumes qualify as supplements to low quality forages.

Forages are the least expensive feed resources for small ruminants yet because of low pasture quality and accessibility they become low during the dry season (Njoya et al., 2005). As indicated by Bamikole et al. (2003) that the bulk of the feeds available to ruminants in the tropics is the grass forage, as this can be sourced inexpensively. In an effort to reduce ruminant feed supply issues, because the grasses are low in crude protein and insufficiently available in dry season, farmers need not to rely solely on natural pastures however needs to practice improved pasture management (Bamikole, 1998). Forages are conserved using different methods. Among these methods, silage, hay and haylage making are the most 
widely recognized. However, various problems happen when drying forages in certain areas with heavy rainfall. In this way, ensiling and haylage making are significant with regards to conserving the forage.

Earlier research on forage conversation showed that there are innate issues in conservation of forages as hay and the right climatic conditions appropriate for hay making harmonize with when forages are low in nutritive value while making good quality hay during the wet season when the forages are of good quality, is basically impossible because of humid weather conditions (Amodu and Abubakar, 2004). Ensilage is another method of forage conservation during the wet season while retaining nutrient quality of the forage without recourse to the utilization of fuel or solar energy for artificial hay making wet, humid conditions (Kallah et al., 1997). Ensilage involves the use of forages, crop residues or agricultural and industrial by-products preserved by acids either added or produced natural fermentation (Babayemi, 2009). Cowan (2000) also reported that silage had played an uneven role by improvement in pastures and forage crop conservation. He focused on harvesting and storage of excess growth of forage in the growing season for feeding during the dry season is important. Silage technology is preferred in the tropics since it is less subject to climate condition, sun drying and artificial drying than hay. Silage can be stored for quite a long time or years (Wong, 1999) and can be utilized whenever it is required particularly during the dry season (Koon, 1993). Therefore, this study aims to examine the physical characteristics and qualities of Panicum maximum (Ntchisi) and Stylosanthes guianensis silage at different proportions and ensiling period.

\section{Materials And Methods Experimental site}

The silage making was carried out the Directorate of University Farms (DUFARMS) and the chemical analysis was carried out at the Laboratory of Pasture and Range Management, College of Animal Science and Livestock Production, Federal University of Agriculture, Abeokuta.

\section{Experimental design}

The study was laid out a $2 \times 3$ factorial design comprising two (2) mixing proportions (Panicum maximum (Ntchisi) $100 \%$ and $50 \%$ of Panicum maximum (Ntchisi) : $50 \%$ of Stylosanthes guianensis) and three (3) ensiling periods (30, 60, and 90 days) and which was replicated four (4) times.

\section{Treatments combination}

$100 \%$ of Panicum maximum (Ntchisi) at 30 days ensiling period

$50 \%$ of Panicum maximum (Ntchisi) and 50\% of Stylosanthes guianensis at 30 days ensiling period 100\% of Panicum maximum (Ntchisi) at 60 days ensiling period

$50 \%$ of Panicum maximum (Ntchisi) and 50\% of Stylosanthes guianensis at 60 days ensiling period 
$50 \%$ of Panicum maximum (Ntchisi) and 50\% of Stylosanthes guianensis at 90 days ensiling period.

\section{Sourcing of plant materials}

Panicum maximum (Ntchisi) and Stylosanthes guianensis were harvested at vegetative stage in an already established field at Directorate of University Farms (DUFARMS) within the University premises.

\section{Silage making}

After harvesting the plant materials, the forages was wilted in order to reduce the moisture contents, and then chopped manually.

- Ensiling 100\% of Panicum maximum (Ntchisi), the silo was weighed, ensiled with grass and reweighed in order to determine the quantity of grass the silo could contain.

- Ensiling 50\% of Panicum maximum (Ntchisi) and $50 \%$ of Stylosanthes guianensis, the determined quantity for the ensiled $100 \%$ Panicum maximum was divided into 2 and ensiled.

\section{Physical evaluation of silage}

Physical characteristics (odour, mouldiness and colour) were determined and ranked according to Bates (1998a) ranking.

\section{Determination of silage $\mathrm{pH}$}

After each ensiling periods (30, 60 and 90 days), the silos were opened and $10 \mathrm{~g}$ of each samples were weighed per each replicate and soaked in $100 \mathrm{ml}$ of distilled water for 1 hour, the mixture was filtered, then $\mathrm{pH}$ was determined using the $\mathrm{pH}$ meter.

\section{Chemical analysis}

Proximate composition: the dry matter, crude protein, ether extract and ash was determined according to A.O.A.C. (2000) while non-fibre carbohydrate will be calculated as NFC $=100-(C P+A s h+E E+N D F)$. Fibre fraction: Neutral detergent fibre (NDF), Acid detergent fibre (ADF) and Acid detergent lignin (ADL) was determined with the procedure of Van soest et al. (1991). Cellulose content was taken as the difference between $A D F$ and $A D L$ while hemicellulose content was calculated as the difference between NDF and ADF.

\section{Statistical analysis}

Data collected was subjected to Two-way analysis of variance and the treatment means will be separated using Duncan's Multiple Range Test using SAS (1999) package.

\section{Results}


The physical characteristics of Panicum maximum (Ntchisi) and Stylosanthes guianensis silage as affected by forage proportion were not significantly $(p>0.05)$ different as shown in Table 1 . There was only significant $(\mathrm{p}<0.05)$ different on $\mathrm{pH}$ as affected by ensiling periods whereby the $\mathrm{pH}$ values decline as the ensiling periods increases. Table 2 shows there was no significant $(p>0.05)$ different on the physical characteristics of $P$. maximum and $S$. guianensis silage as affected by interaction between forage proportion and ensiling periods except $\mathrm{pH}$ value. The $\mathrm{pH}$ values significantly $(\mathrm{p}<0.05)$ ranged from 4.07 in sole $P$. maximum ensiling at 90 days to 4.73 in the same treatment ensiled at 30 days periods.

Proximate composition of $P$. maximum and $S$. guianensis silage at different proportions and ensiling periods are shown in Table 3. Results showed that there was no significant $(p>0.05)$ difference on effect of proportion on the proximate composition of $P$. maximum and $S$. guianensis silage except crude protein (CP) and non fibre carbohydrate (NFC) contents. The highest CP (10.75\%) and NFC (15.33\%) contents was observed in equal proportion of $P$. maximum and $S$. guianensis silage. Also, the ensiling period effect on the proximate composition was significant $(\mathrm{p}<0.05)$ whereby $P$. maximum and $S$. guianensis ensiled for 90 days recorded the highest value for dry matter (DM) (96.88\%) and ether extract (EE) (5.50) while $P$. maximum and S. guianensis ensiled for 30 days had highest $\mathrm{CP}$ content of $12.70 \%$ and the least content $(8.17 \%)$ was observed in silage at 90 days. Forage ensiled at 90 days recorded highest $(20.83 \%)$ NFC content and the least value (10.42\%) were observed in silage at 30 days ensiling period (Table 3 ).

The interaction effect of proportions and ensiling periods on proximate composition of $P$. maximum and $S$. guianensis silage was significant $(\mathrm{p}<0.05)$ except ash content. Equal proportion of $P$. maximum and $S$. guianensis ensiling at 90 days recorded the highest $(97.00 \%)$ DM value $(97.00 \%)$ while sole $P$. maximum ensiled at 60 days had the least value (94.00\%). Sole $P$. maximum ensiled at 30 days had the least (3.50\%) ether extract content and highest (5.75\%) content was observed in the same proportion ensiled at 90 days. The CP content declines in both proportion as the ensiling periods increases $(30>60>90)$ in which the highest $(13.17 \%)$ content was recorded in equal proportion ensiling at 30 days and the least value $(7.80 \%)$ was observed in sole $P$. maximum ensiled at 90 days. Equal proportion of $P$. maximum and $S$. guianensis ensiled at 90 days had the highest (21.70\%) content of non fibre carbohydrate (NFC) and least $(10.26 \%)$ content recorded in sole P. maximum ensiled at 30 days (Table 4$)$.

The results of the fibre composition of $P$. maximum and $S$. guianensis silage at different proportions and ensiling periods are shown in Table 5. Results obtained showed that there was significant $(p<0.05)$ difference on effect of proportion on the neutral detergent fibre (NDF), acid detergent fibre (ADF) and cellulose contents. Sole P. maximum silage had higher NDF (59.67\%), ADF (33.83\%) and cellulose (29.17\%) contents compared to other proportion. There was declined in NDF and ADF contents as the ensiling period extended from 30 to 90 days in which silage ensiled at 90 days had the least content of 54.00 and $32.25 \%$ respectively although there were no statistically difference in NDF between silage ensiled at 30 and 60 days. There were no specific trends in acid detergent fibre (ADL) and hemicellulose contents and the silage ensiled at 30 days had the highest (30.31\%) cellulose content. 
The interaction effect of proportions and ensiling periods on fibre composition of $P$. maximum and $S$. guianensis silage was significant $(p<0.05)$ as presented in Table 4 . There was a declined in NDF and ADF contents as affected by interaction between proportion and ensiling periods and no specific trends in the $\mathrm{ADL}$, hemicellulose and cellulose contents of the silage. Sole P. maximum ensiled at 30 and 60 days recorded the highest $(62.00 \%)$ NDF content while the same treatment ensiled at 30 and 90 days had highest (35.50\%) content of ADF with the lowest (31.00\%) recorded in equal proportion of P. maximum and $S$. guianensis ensiled at 90 days.

Table 1

Effects of forage proportion and ensiling periods on physical characteristics of $P$. maximum and $S$. guianensis silage

\begin{tabular}{|lllll|}
\hline Factors & Colour & Odour & Mouldiness & pH \\
\hline Proportion (\%) & & & & \\
\hline 100 & 11.67 & 24.25 & 9.42 & 4.40 \\
\hline $50: 50$ & 11.75 & 24.00 & 9.17 & 4.46 \\
\hline S E M & 0.23 & 0.55 & 0.22 & 0.07 \\
\hline Ensiling periods (days) & & & & $4.64^{\mathrm{a}}$ \\
\hline 30 & 11.13 & 23.13 & 9.13 & $4.43^{\mathrm{b}}$ \\
\hline 60 & 11.88 & 24.75 & 9.38 & $4.23^{\mathrm{c}}$ \\
\hline 90 & 11.38 & 24.50 & 9.38 & 0.07 \\
\hline S E M & 0.27 & 0.63 & 0.27 & \\
\hline $\begin{array}{l}\text { a, b, c }: \text { Means in same column for each factor with different superscripts are significantly }(\mathrm{p}<0.05) \\
\text { different. }\end{array}$ & & & \\
\hline
\end{tabular}

SEM = Standard Error of Mean 
Table 2

Interaction effects of forage proportion and ensiling periods on physical characteristics of $P$. maximum and $S$. guianensis silage

\begin{tabular}{|llllll|}
\hline Proportion (\%) & Ensiling periods (days) & Colour & Odour & Mouldiness & pH \\
\hline 100 & 30 & 11.00 & 23.00 & 9.25 & $4.73^{\mathrm{a}}$ \\
\hline $50: 50$ & 60 & 11.75 & 24.50 & 9.50 & $4.41^{\mathrm{b}}$ \\
\hline & 30 & 10.75 & 25.25 & 9.50 & $4.07^{\mathrm{c}}$ \\
\hline & 11.25 & 23.25 & 9.00 & $4.55^{\mathrm{ab}}$ \\
\hline \begin{tabular}{l} 
S E M \\
\hline
\end{tabular} & 90 & 12.00 & 25.00 & 9.25 & $4.46^{\mathrm{ab}}$ \\
\hline $\begin{array}{l}\text { a, b, c }: \text { Means in same column for each factor with different superscripts are significantly }(\mathrm{p}<0.05) \\
\text { different. }\end{array}$ & 12.00 & 23.75 & 9.25 & $4.37^{\mathrm{b}}$ \\
\hline
\end{tabular}

SEM = Standard Error of Mean

Table 3

Effects of forage proportion and ensiling periods on the proximate composition (\%) of $P$. maximum and $S$. guianensis silage

\begin{tabular}{|llllll|}
\hline Factors & Dry matter & Ether extract & Crude protein & Ash & NFC \\
\hline Proportion (\%) & & & & & \\
\hline 100 & 95.58 & 4.83 & $10.06^{\mathrm{b}}$ & 11.83 & $13.60^{\mathrm{b}}$ \\
\hline $50: 50$ & 96.42 & 4.91 & $10.75^{\mathrm{a}}$ & 11.83 & $15.33^{\mathrm{a}}$ \\
\hline SEM & 0.45 & 0.29 & 0.56 & 0.31 & 1.46 \\
\hline Ensiling periods (days) & & & & & \\
\hline 30 & $95.75^{\mathrm{ab}}$ & $4.38^{\mathrm{b}}$ & $12.70^{\mathrm{a}}$ & 12.00 & $10.42^{\mathrm{b}}$ \\
\hline 60 & $95.38^{\mathrm{b}}$ & $4.75^{\mathrm{b}}$ & $10.35^{\mathrm{b}}$ & 12.00 & $12.15^{\mathrm{b}}$ \\
\hline 90 & $96.88^{\mathrm{a}}$ & $5.50^{\mathrm{a}}$ & $8.17^{\mathrm{c}}$ & 11.50 & $20.83^{\mathrm{a}}$ \\
\hline SEM & 0.47 & 0.31 & 0.13 & 0.38 & 0.70 \\
\hline a, b, c: Means on same column with different superscripts are significantly $(\mathrm{p}<0.05)$ different \\
\hline
\end{tabular}

SEM = Standard Error of Mean 
NFC = Non Fibre Carbohydrate

Table 4

Interaction effects of forage proportion and ensiling periods on the proximate composition (\%) of $P$. maximum and $S$. guianensis silage

\begin{tabular}{|lllllll|}
\hline $\begin{array}{l}\text { Proportion } \\
(\%)\end{array}$ & $\begin{array}{l}\text { Ensiling periods } \\
\text { (days) }\end{array}$ & $\begin{array}{l}\text { Dry } \\
\text { matter }\end{array}$ & $\begin{array}{l}\text { Ether } \\
\text { extract }\end{array}$ & $\begin{array}{l}\text { Crude } \\
\text { protein }\end{array}$ & Ash & NFC \\
\hline 100 & 30 & $96.00^{\mathrm{ab}}$ & $3.50^{\mathrm{c}}$ & $12.24^{\mathrm{b}}$ & 12.00 & $10.26^{\mathrm{c}}$ \\
\hline & $94.00^{\mathrm{b}}$ & $5.25^{\mathrm{ab}}$ & $10.16^{\mathrm{d}}$ & 12.00 & $10.59^{\mathrm{c}}$ \\
\hline $50: 50$ & $96.75^{\mathrm{a}}$ & $5.75^{\mathrm{a}}$ & $7.80^{\mathrm{f}}$ & 11.50 & $19.5^{\mathrm{a}}$ \\
& 90 & $95.50^{\mathrm{ab}}$ & $5.25^{\mathrm{ab}}$ & $13.17^{\mathrm{a}}$ & 12.00 & $10.58^{\mathrm{c}}$ \\
& 60 & $96.75^{\mathrm{a}}$ & $4.25^{\mathrm{bc}}$ & $10.54^{\mathrm{c}}$ & 12.00 & $13.71^{\mathrm{b}}$ \\
\hline SEM & $97.00^{\mathrm{a}}$ & $5.25^{\mathrm{ab}}$ & $8.55^{\mathrm{e}}$ & 11.50 & $21.70^{\mathrm{a}}$ \\
\hline a, b, c...f. Means on the same column with different superscripts are significantly $(\mathrm{p}<0,05)$ different \\
\hline SEM = Standard Error of Mean, NFC = Non Fibre Carbohydrate & & & \\
\hline
\end{tabular}

Table 5

Effects of forage proportion and ensiling periods on the fibre composition (\%) of P. maximum and S. guianensis silage

\begin{tabular}{|llllll|}
\hline Factors & NDF & ADF & ADL & Hemicellulose & Cellulose \\
\hline Proportion (\%) & & & & & \\
\hline 100 & $59.67^{\mathrm{a}}$ & $33.83^{\mathrm{a}}$ & 4.67 & 25.83 & $29.17^{\mathrm{a}}$ \\
\hline $50: 50$ & $57.17^{\mathrm{b}}$ & $32.33^{\mathrm{b}}$ & 4.66 & 24.83 & $27.67^{\mathrm{b}}$ \\
\hline SEM & 0.97 & 0.51 & 0.38 & 0.89 & 0.53 \\
\hline Ensiling periods (days) & & & & & \\
\hline 30 & $60.50^{\mathrm{a}}$ & $34.75^{\mathrm{a}}$ & $4.44^{\mathrm{b}}$ & $25.75^{\mathrm{b}}$ & $30.31^{\mathrm{a}}$ \\
\hline 60 & $60.75^{\mathrm{a}}$ & $32.25^{\mathrm{b}}$ & $5.12^{\mathrm{a}}$ & $28.50^{\mathrm{a}}$ & $27.13^{\mathrm{b}}$ \\
\hline 90 & $54.00^{\mathrm{b}}$ & $32.25^{\mathrm{b}}$ & $4.43^{\mathrm{b}}$ & $21.75^{\mathrm{c}}$ & $27.82^{\mathrm{b}}$ \\
\hline SEM & 0.78 & 0.59 & 0.18 & 0.88 & 0.69 \\
\hline a, b, c; Means on same column with different superscripts are significantly $(\mathrm{p}<0.05)$ different \\
\hline
\end{tabular}


NDF $=$ Neutral detergent fibre

ADF $=$ Acid detergent fibre

$A D L=$ Acid detergent lignin

SEM $=$ Standard error of mean

Table 6

Interaction effects of proportion and ensiling periods on the fibre composition (\%) of P. maximum and $S$. guianensis silage

\begin{tabular}{|lllllll|}
\hline Proportion & Ensiling periods (days) & NDF & ADF & ADL & Hemicellulose & Cellulose \\
\hline 100 & 30 & $62.00^{\mathrm{a}}$ & $35.50^{\mathrm{a}}$ & $3.96^{\mathrm{e}}$ & $26.50^{\mathrm{ab}}$ & $31.54^{\mathrm{a}}$ \\
\hline & 60 & $62.00^{\mathrm{a}}$ & $32.50^{\mathrm{bc}}$ & $4.18^{\mathrm{d}}$ & $29.50^{\mathrm{a}}$ & $28.32^{\mathrm{b}}$ \\
\hline $50: 50$ & 50 & $55.00^{\mathrm{c}}$ & $35.50^{\mathrm{a}}$ & $5.86^{\mathrm{b}}$ & $21.50^{\mathrm{c}}$ & $27.64^{\mathrm{bc}}$ \\
& 50 & $59.00^{\mathrm{ab}}$ & $34.00^{\mathrm{ab}}$ & $4.92^{\mathrm{c}}$ & $25.00^{\mathrm{bc}}$ & $29.01^{\mathrm{b}}$ \\
& 50 & $59.50^{\mathrm{ab}}$ & $32.00^{\mathrm{bc}}$ & $6.06^{\mathrm{a}}$ & $27.50^{\mathrm{ab}}$ & $25.94^{\mathrm{c}}$ \\
\hline SEM & $53.00^{\mathrm{c}}$ & $31.00^{\mathrm{c}}$ & $2.99^{\mathrm{f}}$ & $22.00^{\mathrm{c}}$ & $28.01^{\mathrm{bc}}$ \\
\hline a, b, c...f. Means on same column with different superscripts are significantly $(\mathrm{p}<0.05)$ different \\
\hline
\end{tabular}

NDF $=$ Neutral detergent fibre

ADF = Acid detergent fibre

$A D L=$ Acid detergent lignin

SEM $=$ Standard error of mean

\section{Discussion}

Silage production is a convention forage conservation strategy which requires the utilization of high yielding forage species per unit area. In mixed grass-legume silage, grass gives the fermentable carbohydrate while the legumes further improve the protein content of the silage. Silage $\mathrm{pH}$ is a significant parameter in the long term stability of ensiled forages. For example, forages with low buffering capacity permits a pH drop quickly even when acid production is little (Alli et al., 1983). This however, might be impacted by the moisture content and the buffering capacity of the original materials. Silage that has been properly fermented will have much lower $\mathrm{pH}$ (be more acidic) than the original forage. Reduction in pH in this study was similar to value reported by Phillip et al. (2007) and Shahabodin 
et al. (2014) and this reduction was as a result of increase in ethanol content of the silage as the ensiling periods progressed (Driehius and Wikselaar, 2000). The $\mathrm{pH}$ value recorded in this study as influenced by forage proportion and ensiling periods is higher than that recommended as the normal pH of 4.2 (Kung and Shaver, 2001) and the difference might be as a result of environmental factors such as temperature and ensiling grass with the legume produced silages with moderate $\mathrm{pH}$ values (Muhammed et al., 2008).

Incorporation of legumes in silages resulted to increases in the nutritional characteristics (dry matter (DM), crude protein (CP), ether extract (EE) and ash contents) with corresponding decline in structural constituents (Neutral detergent fibre (NDF), acid detergent fibre (ADF) and acid detergent lignin (ADL) in all treatment examined. This suggested that inclusion of $50 \%$ legume improves the ensiling quality of grass at full bloom stage of maturity. Dry matter (DM) content declined as the ensiling periods progressed and the reduction could be clarified by a moderate fall in reducing sugar which is similar to the findings of Henk and Linden (1992) and Stokes and Chen (1994) for sweet sorghum and corn silage, respectively. This reduction was attributed to the continued maintenance requirement of the microbial population in the silage.

Crude protein (CP) content of the silage produced from combinations of grass and legume was above the $\mathrm{CP}$ critical level of $8 \%$ (Norton, 1994) acceptable for ruminant performance and the CP recorded for the silages were well above the threshold of $60 \mathrm{~g} / \mathrm{kg}$ needed by rumen microbes to build their protein body, below this threshold, intake of forages by ruminants and rumen microbial activity would be adversely affected (Van Soest, 1994). The CP content of the silages in this study was higher than the critical value of $70 \mathrm{~g} / \mathrm{kg}$ recommended for small ruminants (NRC, 1981). The silages will also be adequate in providing high quality protein supplement to non-lactating ruminants during the dry season. The CP content of silage in this study fell within the range of $6.54-15.15 \%$ reported by Ukanwoko and Igwe (2012) and also fell within the report of Anele et al. (2011) for grass and legume silage but higher than that reported by Babayemi (2009) for sole $P$. maximum which might be as a result of nutrient composition of original forage. The $\mathrm{CP}$ content also decreased with increase in the ensiling periods from 30 to 90 days after ensiling. The decrease in the CP content of the silage recorded in this study concurred with the reports of Akinola (2008) and Jolaosho et al. (2013) when guinea grass, cassava peel, brewery and pineapple wastes were ensiled at different proportion. Meanwhile, the CP contents of silages in this study as affected by ensiling periods are higher than $7 \%$ as the level considered as minimal requirements for ruminant animals according to Van Soest (1994). Non fibre carbohydrate (NFC) recorded in this study fell within the range of $127-259 \mathrm{~g} / \mathrm{kg}$ reported by Anele et al. (2009). This shows that NFC of this grass legume silage can be easily degraded or fermented as NFC is a crude estimate of the carbohydrate pool that differ in digestibility from NDF. It has also been reported that NFC has positive relationship with ammonia nitrogen (NH3-N) utilization in the rumen (Tylutki et al., 2008).

The contents of NDF and ADF declined from 30 to 90 days. The reduction in the NDF and ADF contents of the silage with increase in ensiling periods as observed was in accordance with the findings of Akinola (2008) which might be ascribed to degradation of cell wall by the activity of bacterial enzyme (cellulose and hemicellulose) and production of organic acids during fermentation (Yahaya et al., 2001). Kung and 
Shaver (2001) suggested that higher content of NDF in silage usually indicated that many of the soluble nutrients have been damaged which reduces the nutritive value of the silage. The higher the ADF, the less digestible the feed and the less energy it will contain (McDonald et al., 1991). The Acid Detergent Lignin $(A D L)$ content of the silages under this study were slightly higher than those reported by Shahabodin et al. (2014) for sweet sorghum silage but lower than the findings of Jolaosho et al. (2013) for silages produced from Guinea grass and agro by-products.

\section{Conclusion}

The significance of silage cannot be overemphasized, aside from providing feed to animals particularly during dry season; it also preserves the nutrient in the forage materials. The inclusion of legume in grass silage has beneficial advantages to silage qualities. This study showed that the periods of ensiling changed the qualities of the grass - legume silage and it is therefore concluded that the composite silage made from $50 \%$ P. maximum and 50\% S. guianensis was the best in terms of CP content and with relatively least fibre fraction. The silage ensiled for 30 days also had the highest $\mathrm{CP}$ value. The $\mathrm{CP}$ of the silage being higher than the minimum requirement for maintenance of ruminant animals across the three ensiling periods (30, 60 and 90 days) makes them a good supplement for dry season feeding.

\section{Declarations}

Funding: Nofunding was received from any organization for the submitted work

Conflict of interest: The authors declare that they have no conflict of interest

Statement of animal right: Not applicable

Availability of data and material: Data will be made available on request.

Code availability: Not applicable

\section{Authors' contribution:}

Okukenu, O. A. conceived of the study and drafted the manuscript.

Okunogbe, S. O. participated in the design of the study.

Afolabi, R. A. carried out the laboratory analysis

Dele, P. A. was in charge of data analysis

Akinyemi, B. T. helped in field work

Amisu, A. A. helped in the design of the study 
Jolaosho, A. O. and Onifade, O. S. coordinated and help in critique the manuscript

All authors read and approved the final manuscript

\section{References}

A.O.A.C. 2000. Official methods of analysis $15^{\text {th }}$ edition. Association of Official Analytical Chemists, Washington D.C.

Akinola, T.O. 2008. "Quality of Silage Made from Guinea Grass, Cassava Peel and Pineapple Waste”. M. Agric. Dissertation, Department of Pasture and Range Management, University of Agriculture: Abeokuta, Nigeria. 93pp.

Alli, I., Fairbairn, R. and Baker, B.E. 1983. The effects of ammonia on fermentation of chopped sugarcane. Animal Feed Science and Technology, 9:291-299.

Amodu, J. T and Abubakar S.A. 2004. Forage conservation practices. Proceedings of Training Veterinary management in Nigeria held at the National Animal Production Research Institute, October 10-14. Abuja.

Amole, T. A., Ojo, V. O. A., Dele, P. A., Adeoye, S. A., Onifade O. S., Jolasho, A. O., Olanite, J. A and Oyewole, S. T. 2011. Nutrient Digestibility of Calves Fed Maize - Lablab Silage Supplement 2011, Proceeding 36th Conference, Nigeria Society for Animal Production. 13-16 March. Pp 485-487.

Anele, U. Y., Arigbede, O. M., Südekum, K.-H., Oni, A. O., Jolaosho, A. O., Olanite, J. A., Adeosun, A. I., Dele, P. A., Ike, K. A. and Akinola, O. B. 2009. Seasonal chemical composition, in vitro fermentation and in sacco dry matter degradation of four indigenous multipurpose tree species in Nigeria. Animal Feed Science and Technology 154: 47-57.

Anele, U. Y., Jolaosho, A. O., Arigbede, O. M., Olanite, J. A. and Onifade, O. S. 2011. Effects of air drying and plant types on quality of grass/ legume silage. In: Animal Feed: Types, Nutrition and Safety. (Sarah R. Borgearo, ed). pp. 207-218. Nova Science Publishers, Inc. New York, USA.

Babayemi, O. J. 2009. Silage quality, dry matter intake and digestibility by West African dwarf sheep of Panicum maximum (Panicum maximum cv Ntchisi) harvested at 4 and 12 week regrowths. African Journal of Biotechnology. Vol.8 (16) pp3983-3988.

Bamikole, M. A., Ikhatua, U. J., Anota, B. and Omaduvie, F. 2003. Feed intake, feed utilization and weight gain of West African dwarf goats fed varying proportions of Ficus religosia and Panicum maximum. Proceedings 28th Annual conference of Nigeria Society for Animal production, held at I.A.R.T, Obafemi Awolowo University, Moor Plantation, Ibadan, 16th - 20th March (2003).Pp 274 -278.

Bates, G. 1998a. Corn silage. The University of Tennessee Agricultural Extension Service SP434-D 
Cowan. T. 2000. Use of ensiling forages in large scale animal production systems in the tropics. Paper presented in the FAO e- conference on tropical Silage, September 7th -15th December 1999. P.29-37, in FAO, 2000, q.v

Driehuis, F. and Van Wiskelaar, P. G. 2000. The occurrence and prevention of ethanol fermentation in highdry-matter grass silage. Journal of the Science of food and Agriculture, 80:711-718.

Elliot, R. and McMeniman, N. P. 1987 Supplementation of ruminant diets with forage. The nutrition of herbivores $\rrbracket$. (Eds JB Hacker, JH Ternouth) (Academic Press: Sydney)

Henk, L. L. and Linden, J. C. 1992. Simultaneous ensiling and enzymatic hydrolysis of structural polysaccharides. Enzyme and Microbial Technology, 14: 923-930.

Jolaosho, A., P. Dele, J. Olanite, O. Arigbede, V. Ojo, and O. Okukenu. 2013. "Chemical Composition of Silage from Guinea Grass, Cassava Peel, and Brewery Waste as Affected by Ensiling Duration". Pacific Journal of Science and Technology. 14(2):463-467.

Koon, L. L. 1993. Production of silage from fodder grass species for dry season feeding. In: Strategies for suitable forage-based livestock production in S. E. Asia. Proc. 3rd Meet. Region.Working Grp. On Grazing and Feed Resources for S. E. Asia. 31st Jan - 6th Feburary. (1993) KhonKaen, Thailand pp. 99-101.

Kung, L. and Shaver, R. 2001. Interpretation and use of silage fermentation analysis reports. Forage Research Centre, Madison, Wisconsin, USA

McDonald, P., Henderson, A.R. and Heron J.J.E. 1991. The biochemistry of silage. Charcombe Publications, Buckinghamshire, U.K.

Muhammad, I. R., Baba, M., Mustapha, A., Ahmad M.Y. and Abdulrahman, L. S., 2008. Use of Legume in the Improvement of Silage Quality of Columbus Grass (Sorghum almum Parodi). Research Journal of Animal Sciences 2(4): 109-112, 2008.

Muhammad, I. R., Baba, M., Mustapha, A., Ahmad M.Y. and Abdulrahman, L. S., 2008. Use of Legume in the Improvement of Silage Quality of Columbus Grass (Sorghum almum Parodi). Research Journal of Animal Sciences 2(4): 109-112, 2008.

National Research Council (NRC) 1981. Nutrient requirement of goats. Angora, Dairy and meat goats in temperate and tropical countries. National Academy of Sciences Washington, DC.

Njoya, A., Awa, D.N. and Chupamom J. 2005. The effects of a strategic supplementation and prophilaxis on the reproductive performance of primiparousfulbe ewes in the semi-arid zone of Cameroon. Small ruminant Research 56(1-3): 21-29.

Norton, B.W. 1994. Tree legumes as dietary supplements for ruminants. In: Gutteridge RC, Shelton, HM (editors). Forage tree legumes in Tropical Agriculture, CAB International. Pp192 - 201. 
Philipp, D., Moore, K.J., Pedersen, J.F., Grant, R.J., Redfearn, D.O. and Mitchell, R.B. 2007. Ensilage performance of sorghum hybrids varying in extractable sugars. Biomass and Bioenergy, 31:492-496.

Shahabodin, Z.N., Nima, K.E., Ebrahim R. and Alireza B. 2014. Influence of ensiling time on chemical composition, fermentation characteristics, gas production and protein fractions of sweet sorghum silage. Research Options in Animal and Veterinary Sciences. Pp 286-293.

Statistical Analysis System Institute Inc., 1999. SAS/24. STAT Programme, Carry, NC: SAS Institute Inc.

Tylutki, T. P., Fox, D. G., Durbal, V. M., Tedeschi, L. O., Russell, J. B., Van Amburgh, M. E., Overton, T. R., Chase, L. E. and Pell, A. N. 2008. Cornell Net Carbohydrate and Protein System: A model for precision feeding of dairy cattle. Animal Feed Science and Technology 143: 174-202.

Ukanwoko, A. I. and Igwe, N. C. 2012. Proximate Composition of Some Grass and Legume Silages Prepared in a Humid Tropical Environment International Research Journal of Agricultural Science and Soil Science 2(2): 68-71

Van Soest, P. J. 1994. Nutritional ecology of the ruminant, $2^{\text {nd }}$ edn. Ithaca, NY USA: Comstock Publishing Associates/Cornell University Press. 476pp

Van Soest, P.J., Robertson J.B. and Lewis B.A. 1991. Methods for dietary fiber, neutral detergent fiber, and non starch polysaccharides in relation to animal nutrition. J. Dairy Sci., 74: 3583-3597.

Wong, C. C. (1999). The place of silage in ruminant production in the humid tropic. In: L囚t Mannetje (Ed.) Proc. FAO e- Conf. on Trop. Silage. FAO plant Prod. And Protect. Paper 161. 1st September - 15th December, (1999). Poster 1.1:5-6.

Yahaya, M.S., Kimura, A., Harai, J., Nguyen, H.V., Kawai, M., Takahashi, J. and Matsuoka, S. 2001. Effect of length of ensiling on silo degradation and digestibility of structural carbohydrates of lucerne and orchardgrass. Animal Feed Science and Technology, 92: 141-148. 